\title{
Passive immunization of channel catfish Ictalurus punctatus with anti - Flavobacterium columnare sera
}

\author{
R. A. Shelby*, C. A. Shoemaker, P. H. Klesius \\ Aquatic Animal Health Research Laboratory, Agricultural Research Service, U.S. Department of Agriculture, 990 Wire Road, \\ Auburn, Alabama 36832, USA
}

\begin{abstract}
Passive immunization of channel catfish Ictalurus punctatus (Rafinesque) was conducted to determine if anti-Flavobacterium columnare serum was protective when injected intraperitoneally (i.p.) into channel catfish. The anti-F. columnare serum was produced by actively immunizing (i.p. injection) channel catfish with sonicated whole cells or purified lipopolysaccharide (LPS) of F. columnare in Freund's adjuvant. Serum anti-F. columnare activity was verified by Western blotting and ELISA of serum. Normal serum and sterile culture broth were used as controls. Complement was inactivated in all sera by heating. After $48 \mathrm{~h}$, passively immunized fish were challenged with virulent F. columnare by i.p. injection. A group of unchallenged fish served as controls. The immune response of catfish to the antigenic fractions was different when examined by Western blotting. Antibody produced with whole-cell antigen responded to a broad range of molecular weight components, while LPS antigens were restricted to a pair of bands near $20 \mathrm{kDa}$. Control fish injected with culture medium experienced $100 \%$ mortality 14 d post-challenge. Relative percent survival was 77 and 73 for catfish passively immunized with anti-LPS and anti-whole-cell serum, respectively. Results suggest that antibodies in the serum are involved in the protective immune response against columnaris disease in channel catfish.
\end{abstract}

KEY WORDS: Flavobacterium columnare · Passive immunization Resale or republication not permitted without written consent of the publisher

\section{INTRODUCTION}

Flavobacterium columnare (formerly Flexibacter columnaris) is the causative agent of columnaris disease, and is the second most important pathogen in the cultured channel catfish industry in the United States (Wagner et al. 2002). F. columnare exists in fresh and brackish water throughout the world (Plumb 1999) and affects $>36$ fish species, including eels, salmonids, centrarchids, carps, minnows, perchids and aquarium fishes (Plumb 1999). Our previous research to develop immunoassays for this disease (Shoemaker et al. 2003, $2005 b)$ showed that catfish anti-F. columnare immunoglobulin levels increased in convalescent or vaccinated fish.
Experimental passive immunization has been attempted with varying results in fish, including attempts by interspecific passive transfer of immunity. Akhlaghi et al. (1996) successfully used sheep and rabbit antibody against streptococcal infection in rainbow trout Oncorhynchus mykiss, but mortalities were not reduced after passive immunization with rainbow trout antibodies against Streptococcus sp. Akhlaghi (1999) later used sheep, rabbit and trout anti-Vibrio anguillarum antibodies and was able to reduce mortality in rainbow trout due to vibriosis. Passive immunization has also been attempted in other fish species. LaFrentz et al. (2003) demonstrated protection from coldwater disease caused by Flavobacterium psychrophilum in rainbow trout using serum from convales- 
cent trout, but was unable to produce the same effect using goat anti-F. psychrophilum serum. Lin et al. (1996) induced immunity against Ichthyophthirius multifilis (Ich) in channel catfish using murine monoclonal antibodies. Even within the same species, passive immunization has not always proven to be successful. Klesius \& Sealey (1995) were unable to reduce mortality of catfish to Edwardsiella ictaluri using sera of fish that had survived infection, even though antibody titers were significantly elevated in passively immunized animals.

In our earlier experiments with anti-Streptococcus iniae antibody from Nile tialpia (Shelby et al. 2002), we demonstrated the role of immunoglobulin and protection against this pathogen by passive immunization. From these previous studies on passive immunization with whole sera from immune and normal fish, it was shown that the role of antibody in immunity against fish pathogens can be elucidated. The objective of the present study was to determine if passive immunization of channel catfish with catfish anti-Flavobacterium columnare antiserum could provide protection against columnaris disease. We included different antigen preparations in order to identify the potential antigenic determinants of F. columnare.

\section{MATERIALS AND METHODS}

Bacterium. Flavobacterium columnare isolate ALG00-530 was originally isolated from a diseased channel catfish Ictalurus punctatus from a commercial pond in Greensboro, Alabama, USA, and maintained in pure culture at the USDA-ARS Aquatic Animal Health Research Laboratory, Auburn, Alabama. Isolate ALG00-530 was grown for $24 \mathrm{~h}$ in modified Shieh broth at $28^{\circ} \mathrm{C}$ with shaking at $100 \mathrm{rpm}$ (Shoemaker et al. 2005a). This isolate was grown under similar conditions and used for antibody production as well as subsequent disease challenge.

Fish. Channel catfish (NWAC 103 strain) reared at our laboratory from fry to juveniles were used as experimental animals. Prior to initiation of the study, fish were housed for $14 \mathrm{~d}$ in $55 \mathrm{l}$ glass aquaria using flow-through water $\left(0.5 \mathrm{l} \mathrm{min}^{-1}\right)$, and a photoperiod was maintained on a $12 \mathrm{~h}$ light:12 h dark schedule. Daily water temperature averaged $25 \pm 1^{\circ} \mathrm{C}$, and mean daily dissolved oxygen was $5.5 \pm 0.7 \mathrm{mg} \mathrm{l}^{-1}$. Fish were fed daily ( 3 to $4 \%$ body weight) with commercial trout chow (No. 5104, Purina Mills). Prior to initiation of this study, fish were tested by ELISA (Shoemaker et al. $2003,2005 b$ ) and determined to be negative for antiFlavobacterium columnare antibody. The ELISA test was conducted on plastic microtiter plates (Nunc maxisorp, Nalge Nunc International) coated with $100 \mu \mathrm{l}$ of a solution of $4 \mu \mathrm{g} \mathrm{ml}^{-1}$ of $F$. columnare antigen in $0.05 \mathrm{M}$ sodium carbonate buffer $(\mathrm{pH} 9.6)$ for $1 \mathrm{~h}$ at $25^{\circ} \mathrm{C}$. Antigen for ELISA coating was from the same batch used for the whole-cell sonicate described in detail below. Plates were then rinsed 5 times with PBST (phosphate-buffered saline, $\mathrm{pH} 7.4$ ) $+0.05 \%$ Tween-20. Then, $100 \mu \mathrm{l}$ of fish sera (diluted 1:800 in PBST) was placed in the antigen-coated ELISA wells, and incubated at room temperature for $30 \mathrm{~min}$. Plates were rinsed as above, and mouse anti-catfish immunoglobulin monoclonal Antibody E8 (Klesius 1990, Shoemaker et al. 2003) was added at a concentration of $400 \mathrm{ng} \mathrm{ml}^{-1}$ in PBST. After $30 \mathrm{~min}$ of incubation at $25^{\circ} \mathrm{C}$, plates were washed with PBST. Sheep antimouse IgG peroxidase conjugate (A-5906, Sigma) was diluted 1:5000 in PBST; $100 \mu \mathrm{l}$ was added to each well and incubated for $15 \mathrm{~min}$ at $25^{\circ} \mathrm{C}$. Plates were rinsed with PBST and $50 \mu \mathrm{l}$ of 3,3',5,5'-tetramethylbenzidine (TMB). The peroxidase reaction was stopped after 15 min with $50 \mu \mathrm{l}$ of $3 \mathrm{M} \mathrm{H}_{2} \mathrm{SO}_{4}$ and read spectrophotometrically at $450 \mathrm{~nm}$.

Columnaris antigen production. Different Flavobacterium columnare antigens were used to immunize channel catfish to produce antibody for passive transfer experiments. Briefly, F. columnare ALG-00-530 cells were grown as described above. The broth culture was centrifuged $(4000 \times g$ for $15 \mathrm{~min})$, and the cells were washed in sterile PBS. Whole-cell sonicates were produced by sonicating cells $30 \mathrm{~s}$ on ice and adjusting to $1 \mathrm{mg} \mathrm{ml}^{-1}$ of protein as determined by the BCA protein assay (No. 23225, Pierce Biotechnology). The lipopolysaccharide (LPS) fraction of $F$. columnare ALG-00-530 was also used to immunize channel catfish. ALG-00-530 was grown in $300 \mathrm{ml}$ broth as before, and the LPS was purified by the hot phenol extraction method (Maclean et al. 2001). Antigens and antibodies were examined by Western blotting. Electrophoresis was on 4 to $20 \%$ gradient acrylamide gels (NH-21-420, Life Theraputics). Antigen samples were denatured by heating to $100^{\circ} \mathrm{C}$ for $5 \mathrm{~min}$ in sample buffer containing sodium dodecyl sulfate and mercaptoethanol (BG-165, Life Theraputics). Gels were electrophoretically transferred to polydivinylidene fluoride (PVDF) membranes (Biotrace, Gellman Laboratory) at $30 \mathrm{~V}$ constant voltage, at $5^{\circ} \mathrm{C}$, overnight. Membranes were probed with catfish antiserum diluted 1:1000, followed by monoclonal Antibody E8 at a concentration of $2 \mathrm{\mu g} \mathrm{ml}^{-1}$ for the catfish immunoglobulin (Shoemaker et al. 2003). The appropriate peroxidase conjugate (A9044 antimouse, Sigma-Aldrich) was used at 1:1000 and visualized with 4-chloronapthol.

Donor antibody production. The sonicated wholecell preparation was mixed 1:1 with Freund's complete adjuvant (FCA), and $100 \mu \mathrm{l}$ was injected i.p. into 10 channel catfish $(\sim 15 \mathrm{~g})$. Immunization was repeated 
14 d later with Freund's incomplete adjuvant (FIA), and blood was sampled from the caudal vasculature after an additional $14 \mathrm{~d}$. Anti-whole-cell catfish serum (WCC) was isolated by centrifugation at $500 \times g$ after clotting at room temperature for $1 \mathrm{~h}$ and stored frozen for testing and passive immunization. All sera were heated at $56^{\circ} \mathrm{C}$ for $1 \mathrm{~h}$ in a water bath to denature complement (Drevets \& Campbell 1991). Sera were tested for anti-Flavobacterium columnare antibody by ELISA (Shoemaker et al. 2003), prior to passive immunization. The LPS fraction was lyophilized and dissolved in sterile PBS (1 mg ml-1 w/v), mixed 1:1 with FCA, and $100 \mu \mathrm{l}$ was injected into 5 channel catfish ( 15 g). Booster immunization was with FIA and anti-LPS catfish serum (LPSC) purification and conducted as described above for the anti-sonicated cell serum preparation. An additional group of 10 fish that were not immunized provided control serum (NC).

Passive immunization. Twelve channel catfish, mean weight $4.4 \mathrm{~g}$ (range 3.8 to $5.6 \mathrm{~g}$ ), were placed in 3 replicate aquaria (36 fish per treatment; 180 fish total) as previously described, and allowed to adjust for $1 \mathrm{wk}$ prior to passive immunization. Then, $100 \mu \mathrm{l}$ of each of the 3 anti-Flavobacterium columnare antisera (WCC, LPSC, NC) were injected i.p. into each fish. Three control tanks of fish were similarly injected with sterile, modified Shieh broth, which served as a sham injection control to determine any mortality resulting from handling and injection and to serve as non-immunized challenged controls. Three additional tanks of fish were used as non-injected, non-challenged controls. Forty-eight hours after passive immunization with anti-F. columnare antisera or injection with control serum and/or sterile culture media, the fish were bled to confirm the presence or absence of anti-F. columnare antibody by ELISA.

Disease challenge. Virulent Flavobacterium columnare ALG-00-530 was grown in broth culture for $24 \mathrm{~h}$, as described previously, and adjusted to an optical density of 0.7 at $540 \mathrm{~nm}$ with sterile PBS. Samples were spiral plated on modified Shieh agar to determine colony-forming units (CFU) per milliliter. All fish, with the exception of non-challenged controls, were injected i.p. with $8.79 \times 10^{6} \mathrm{CFU}_{\text {fish }}{ }^{-1} 48 \mathrm{~h}$ after passive immunization (Klesius et al. 1999). Fish were fed twice daily to satiation and monitored for disease signs for $14 \mathrm{~d}$. Mortalities were recorded, and dead fish were removed twice daily.

Statistical analysis. Statistical differences were analyzed by SAS (SAS Institute). Significant differences in mean ELISA values and mean cumulative mortality between treatments were determined by 1-way analysis of variance (ANOVA) using the least significant difference test to determine significant differences at $\mathrm{p}<0.05$.

\section{RESULTS AND DISCUSSION}

\section{Immune sera}

Immunization of channel catfish Ictalurus punctatus with whole-cell sonicates and with phenol-extracted LPS produced a measurable humoral immune response compared to naive fish (Table 1), with cellular antigens producing a higher measurable ELISA response then LPS antigens. Western blotting of whole cells and LPS fractions with these sera revealed distinctly different immune responses (Fig. 1). Blotting whole-cell antigen with WCC antiserum revealed a

Table 1. ELISA absorbance $(450 \mathrm{~nm})$ of catfish Ictalurus punctatus sera used for passive immunization. Each value represents the mean of 10 individual sera diluted 1:3200. Values with different letters are significantly different $(p<0.05)$. LPS: lipopolysaccharide

\begin{tabular}{|lcc|}
\hline Antigen source & Mean absorbance & SD \\
\hline Cells & $0.639 \mathrm{a}$ & 0.194 \\
LPS & $0.478 \mathrm{~b}$ & 0.179 \\
Control & $0.069 \mathrm{c}$ & 0.020 \\
\hline
\end{tabular}

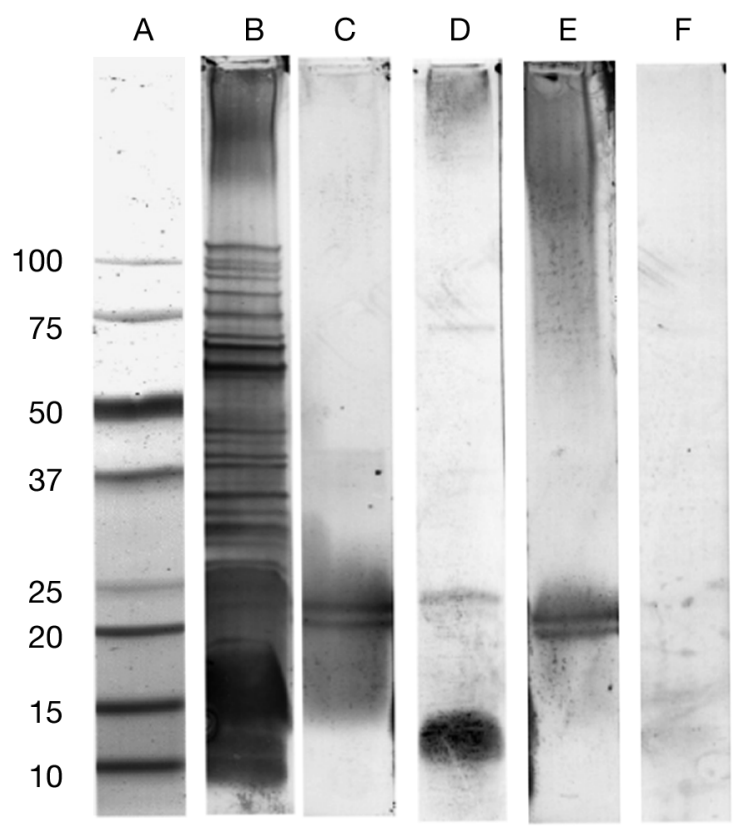

Fig. 1. Western blotting analysis of cellular (Lanes B, D, F) and lipopolysaccharide (LPS) (Lanes C, E) antigens used to produce antiserum for passive immunization. Lane A: prestained molecular weight standards; Lanes B, C: Western blot with channel catfish Ictalurus punctatus anti-Flavobacterium columnare cell antiserum (WCC); Lanes D, E: Western blot with channel catfish anti-F. columnare LPS antiserum (LPSC); Lane F: Western blot with normal channel catfish serum (NC) 
broad size range of putative protein antigens in the whole-cell preparation. The LPS fraction probed with WCC antiserum appears to show only a pair of antigenic bands at about $20 \mathrm{kDa}$. We believe that this represents the core polysaccharide. There does not appear to be a 'ladder-like' profile in the antibody response to the O-antigen as found in Flavobacterium psychrophilum (Maclean et al. 2001) and in Western blots with other gram-negative fish pathogens (Newton \& Triche 1993).

Recently, LaFrentz et al. (2007) demonstrated that the previously described high-molecular size o-polysaccharide of Flavobacterium psychrophilum is actually extracellular polysaccharide glycocalyx. Using LPS antiserum, the whole-cell antigen showed a prominent low-molecular weight band around $15 \mathrm{kDa}$, which was lacking in the LPS preparation. This component is obviously lost in the hot phenol extraction procedure. Also evident are the pair of bands at $20 \mathrm{kDa}$, and polydisperse components (glycocalyx) in the higher molecular weight range. There was no antibody response detected in naive (NC) serum by Western blotting.

\section{Passive immunization}

The passively immunized catfish showed measurable levels of anti-Flavobacterium columnare antibody $48 \mathrm{~h}$ after administration of the immune sera (Fig. 2). Catfish WCC and LPSC sera had ELISA optical density

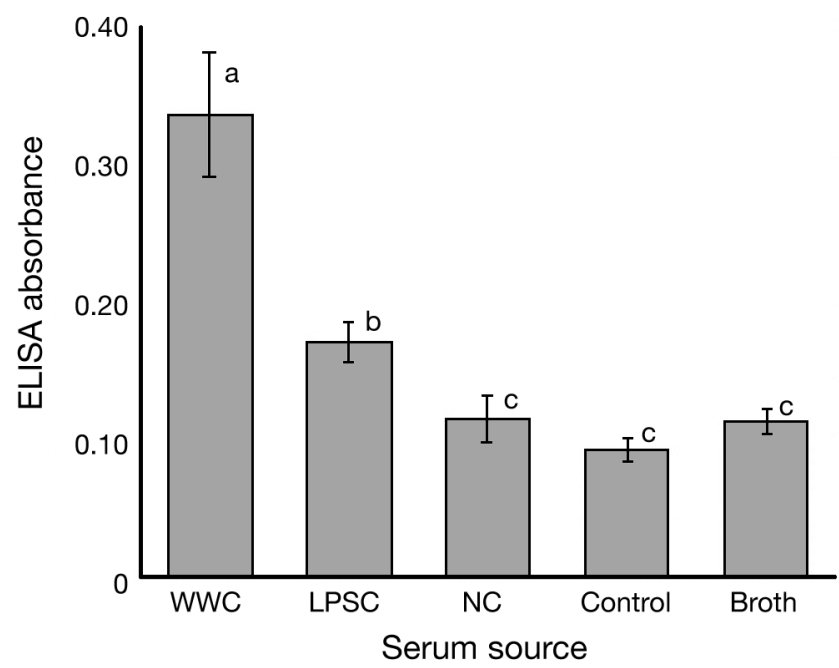

Fig. 2. Specific anti-Flavobacterium columnare antibody level (optical density) measured by ELISA in sera from channel catfish Ictalurus punctatus $48 \mathrm{~h}$ after passive immunization with heat-inactivated anti- $F$. columnare whole-cell catfish (WCC), lipopolysaccharide catfish (LPSC), or normal catfish (NC) antisera. Sterile broth and non-immunized controls were also included. SD indicated by bars. Values with different letters are significantly different $(p<0.05)$
(OD) higher than fish administered normal serum, broth, or no serum. Levels of antigen-specific antibody at $48 \mathrm{~h}$ were generally reflective of the antibody measured in the immune sera.

\section{Disease challenge}

Passive immunization with catfish anti-LPS or antiWC serum resulted in significantly reduced $(p<0.002)$ mortalities compared to broth-injected or normalserum-injected controls (Table 2). Relative percent survival (RPS) was 73 and 77 for catfish passively immunized with anti-LPS and anti-WC serum, respectively, following challenge with the homologous Flavobacterium columnare isolate. Catfish administered normal catfish serum had an RPS of 40. This value is below that estimated to afford protection (i.e. 60; Amend 1981). We also did not detect anti-F. columnare antibody in these fish $48 \mathrm{~h}$ following injection of the serum (i.e. prior to challenge). LaFrentz et al. (2003) demonstrated passive transfer of anti-F. psychrophilum serum in rainbow trout Oncorhynchus mykiss, which resulted in protection against challenge with a virulent isolate of $F$. psychrophilum. Other studies have similarly demonstrated by passive immunization the importance of antibody in protection against other fish pathogens (Akhlaghi 1999, Shelby et al. 2002).

When the LPS fraction of Flavobacterium columnare was tested by Western blotting, catfish showed an antigenic response to a single low-molecular weight fraction typical of the core polysaccharide antigen. The administration of complement-free immune serum from heat-inactivated channel catfish was protective against the homologous challenge by $F$. columnare, suggesting that antibody is important in columnaris disease protection.

Table 2. Ictalurus punctatus. Cumulative percentage mortality and relative percent survival following challenge with Flavobacterium columnare of channel catfish passively immunized with sterile broth, normal catfish serum (NC), anti$F$. columnare whole-cell catfish antiserum (WCC), anti-F. columnare lipopolysaccharide catfish antiserum (LPSC), and non-challenged controls. Values with different letters are significantly different $(\mathrm{p}<0.05)$

\begin{tabular}{|lc|}
\hline Treatment & $\begin{array}{c}\text { Cumulative percent } \\
\text { mortality }( \pm \mathrm{SE})\end{array}$ \\
\hline Shieh broth & $100( \pm 0.0) \mathrm{a}$ \\
Normal whole serum & $60( \pm 5.8) \mathrm{b}$ \\
Anti-LPSC & $27( \pm 14.5) \mathrm{C}$ \\
Anti-WCC & $23( \pm 12.0) \mathrm{C}$ \\
Controls (non-challenged) & $0( \pm 0.0)$ \\
\hline
\end{tabular}


Acknowledgements. The authors thank P. Mumma and N. Qin and the staff of the AAHRU aquatic facility for technological assistance and animal care. Mention of trade names or commercial products in this publication is solely for the purpose of providing specific information and does not imply endorsement by the United States Department of Agriculture.

\section{LITERATURE CITED}

Akhlaghi M (1999) Passive immunization of fish against vibriosis, comparison of intraperitoneal, oral and immersion routes. Aquaculture 180:191-205

Akhlaghi M, Munday BL, Whittington RJ (1996) Comparison of passive and active immunization of fish against streptococcosis (enterococcosis). J Fish Dis 19:251-258

Amend DF (1981) Potency testing of fish vaccines. Dev Biol Stand 49:447-454

Drevets DA, Campbell PA (1991) Roles of complement and complement receptor type 3 in phagocytosis of Listeria monocytogenes by inflammatory mouse peritoneal macrophages. Infect Immun 59:2645-2652

Klesius PH (1990) Effect of size and temperature on the quantity of immunoglobulin in channel catfish, Ictalurus punctatus. Vet Immunol Immunopathol 24:187-195

Klesius PH, Sealey WM (1995) Characteristics of serum antibody in enteric septicemia of catfish. J Aquat Anim Health $7: 205-210$

Klesius PH, Lim C, Shoemaker C (1999) Effect of innate resistance and antibody response to Flavobacterium columnare in channel catfish, Ictalurus punctatus. Bull Eur Assoc Fish Pathol 19:156-158

LaFrentz BR, LaPatra SE, Jones GR, Cain KD (2003) Passive immunization of rainbow trout, Oncorhynchus mykiss (Walbaum), against Flavobacterium psychrophilum, the causative agent of bacterial coldwater disease and rainbow trout fry syndrome. J Fish Dis 26:377-384

Editorial responsibility: Donald Evans, Athens, Georgia, USA
LaFrentz BR, Lindstrom NM, LaPatra SE, Call DR, Cain KD (2007) Electrophoretic and western blot analyses of the lipopolysaccharide and glycocalyx of Flavobacterium psychrophilum. Fish Shellfish Immunol 23:770-780

Lin TL, Clark TG, Dickerson H (1996) Passive immunization of channel catfish (Ictalurus punctatus) against the ciliated protozoan parasite (Ichthyophthirius multifiliis) by use of murine monoclonal antibodies. Infect Immun 64: 4085-4090

Maclean LL, Vinogradov E, Crump EM, Perry MB, Kay WW (2001) The structure of the lipopolysaccharide o-antigen produced by Flavobacterium psychrophilum. Eur J Biochem 268:2710-2716

Newton J, Triche PL (1993) Electrophoretic and immunochemical characterization of lipopolysaccharide of Edwardsiella ictaluri of channel catfish. J Aquat Anim Health 5:246-253

Plumb JA (1999) Health maintenance and microbial diseases of cultured fishes. Iowa State University Press, Ames, IA

Shelby RA, Shoemaker CA, Klesius PH (2002) Passive immunization of tilapia (Oreochromis niloticus) with anti-Streptococcus iniae whole serum. J Fish Dis 25:1-6

Shoemaker CA, Shelby RA, Klesius PH (2003) Development of an indirect ELISA to detect humoral response to Flavobacterium columnare infection of channel catfish (Ictalurus punctatus). J Appl Aquacult 14:43-52

Shoemaker CA, Arias CR, Klesius PH, Welker TL (2005a) Technique for identifying Flavobacterium columnare using whole cell fatty acid profiles. J Aquat Anim Health 18:267-274

Shoemaker CA, Xu DH, Shelby RA, Klesius PH (2005b) Detection of cutaneous antibodies against Flavobacterium columnare in channel catfish, Ictalurus punctatus (Rafinesque). Aquac Res 36:813-818

Wagner BA, Wise DJ, Khoo LH, Terhune JS (2002) The epidemiology of bacterial diseases in food-size channel catfish. J Aquat Anim Health 14:263-272

Submitted: July 11, 2006; Accepted: May 24, 2007

Proofs received from author(s): August 17, 2007 